\title{
Financial knowledge and Literacy or Demographics: What determines the use of Financial Services in Pakistan?
}

\author{
Muhammad Arif ${ }^{1}$, Kashif-ur-Rehman' and Muhammad Zubair Khan ${ }^{2 *}$ \\ ${ }^{1}$ Iqra University, Islamabad, Pakistan; \\ muhammadarifimpcc@gmail.com, drkashif14@gmail.com \\ 2Balochistan University of Information Technology, Engineering, and Management Sciences, Quetta, Pakistan; \\ dr.zubair.statistics@gmail.com
}

\begin{abstract}
Objective: This study was aimed at evaluating the impact of knowledge related and demographic variables on the use of financial services in Pakistan. Methods/Statistical Analysis: The researchers interviewed 150 heads of households with the help of a structured interview schedule, from different parts of the country. The respondents were selected by using the stratified purposive sampling method. The data was analyzed with the help logistic regression and with help of Nvivo-10. Findings: The financial knowledge and information, income level and trust level have positive impact on the decision of using financial services and products in the country. On the contrary, general education level and numeric financial literacy, general level of education, although have an insignificant impact on the decision of using financial services and products. Results of the study highlight the importance of knowledge and information about financial services and products in the decision regarding the usage of financial services and products. Previous studies have focused on numeric and mathematical literacy, which, according to findings of this study is of lesser importance in promoting financial inclusion. Application/Improvements: Results from the study can be utilized by policy makers for devising effective programs for promoting financial literacy and for promotion of financial inclusion in the country.
\end{abstract}

Keywords: Education, Financial, Income, Knowledge, Literacy

\section{Introduction}

The study of factors affecting the usage of financial services and products or participation in financial markets by households has recently received paramount attention, which comes into the ambit of personal finance. Personal finance is the field of finance that studies the way individualmakes use of "financial instruments" to achieve their objectives $^{1}$.
Households are supposed to decide on a number of economic and financial matters which are not the subject matter of corporate finance ${ }^{2}$. The use of financial services and products is highly acknowledged as a factor that contributes to a country's overall economic wellbeing $\underline{3}$. However, the situation with respect to the use of financial countries is not very encouraging, including Pakistan, as only $11 \%$ of the population has access to bank accounts in comparison to that of India where $48 \%$ of the people use

${ }^{*}$ Author for correspondence 
bank accounts, whereas only $4.8 \%$ of women in Pakistan have a bank account as compared to the women of other countries of the region where the percentage of women using bank accounts is $37.4 \%^{4}$. Finance is vital for inclusive growth and the financial market is the mother of all markets; hence it is critical to attain increased financial inclusion in an economy ${ }^{5}$. Contemporary literature has identified number factors responsible for financial exclusion and therefore, it seems logical that these factors are studied in detail because they probably contribute to financial exclusion in a country. Studying the causes of the low financial inclusion ofindividuals is of critical importance. Personal finance studies the financial activities of households carried out by them to achieve their varying objectives ${ }^{1}$.

This study is concerned with investigating the impact of people's financial literacy and knowledge and demographic factors like education, income level, age, dependency ratio and urban rural differences on their decision regarding the usage financial services in Pakistan. The research questions that are supposed to be answered on the basis of this study are as under:

- Does "Numeric Financial literacy" have any impact on financial inclusion?

- Does the "level of financial knowledge and information" have any impact on financial inclusion?

- Do "demographic factors like education; income level, age, dependency ratio and geographical location" have any bearing on financial inclusion or exclusion?

- Does "Trust of people in the financial institutions" have any impact on financial inclusion?

\section{Financial Literacy and financial inclusion:}

Before studying the impact of financial literacy on financial inclusion or exclusion of individuals, it is pertinent to have a look at how researchers define financial literacy. Financial literacy could be defined as the capacity of individuals to use personal financial related information ${ }^{6}$. Financial literacy is different from financial knowledge ${ }^{7}$. The term financial literacy was first coined in 1997․․ Financial literacy may be defined as the capacity of individuals to know and use financial services and products.

Situation of financial literacy is very discouraging in the Pakistan?. The need for financial education has increased in the wake of more sophisticated and complex financial environment ${ }^{10}$. Financial illiteracy amongst young people is very worrisome as it may have long term negative economic impacts ${ }^{11}$. The availability of valid empirical proof to support or refute these theoretical propositions about the financial literacy and use of financial services is still limited ${ }^{12}$. The impact of financial literacy on the use of financial services is yet to be explored $\underline{13}$. Individuals possess different levels of financial literacy ${ }^{14}$. Financial literacy is highly correlated with the degree of portfolio diversification 2 . Financial literacy positively influences informal and formal savings $s^{15}$. Understanding the consumer's insight and approach towards insurance and promoting an insurance culture is important in flourishing the insurance business $\frac{16,17}{}$. The economic wellbeing of an individual is dependent on his financial decision. On the basis of findings of different researchers, it can be said that for making an informed decision, knowledge is a prerequisite. "Financial literacy "has a positive impact on the intention to save ${ }^{18}$. Financial literacy skills my help consumers in avoiding excessive borrowings ${ }^{19}$.

\section{Financial Knowledge and Information}

Financial knowledge "is the stock of knowledge acquired and which is related to essential financial concept and products" $\underline{\text {. }}$. However, other researchers do not differentiate the two concepts. The effective use of financial products and services necessitates the acquisition of financial knowledge and insufficient financial knowledge may result in inefficient financial decisions which may be costly ${ }^{3}$. The study partly derives the theoretical support from the formal theory of knowledge and action. The 
theory proposes that every action is preceded by knowledge, even a simply worldly action just like opening as age lock that cannot be performed without knowledge and therefore, complicated decisions require certain amount knowledge $e^{20}$.

Applying this theory to financial decision, which is an important decision in one's life, it can be said that sufficient knowledge about different financial matters require sufficient knowledge. Likewise applying to this study, we propose that using financial services must be preceded by sufficient information and knowledge. And once people are given with initial knowledge and information, they will feel more motivated towards the usage of formal financial and services and they will use more such services due to the effect of "informative actions".

\section{Trust and the usage of Financial Services}

An individual's decision to deposit his/her money in a bank account is a faithful decision. Therefore, such decisions require certain level of trust in financial institutions. Trust is the expectation that an agent will perform in the best interest of the principal ${ }^{2,21,22}$.

The researchers further argue that an individual's trust is subjective, that varies from situation to situation and from individuals to individuals. The use of banking services requires certain level of trust ${ }^{2}$. The researchers claimed that they have introduced method of measuring trust. They observed that majority of individuals remain hesitant to invest in stock market due to lack of trust. Trust influences the individual's decision to hold a savings account $\frac{23}{3}$.

\section{Demographic Factors and the use of Financial Services}

Researchers have observed that education is one of the contributing factors towards financial inclusion. The level of formal education has a positive significant impact on savings behavior of individuals ${ }^{24}$. The uneducated individuals hesitate to trust others 2 . There are a variety of factors are responsible for limited stock participation, like lack of trust, low education level and risk aversion ${ }^{25}$. Some investors make financial mistakes because of lesser education ${ }^{26}$. Individual characteristics like "education, life expectancy, dependency ratio and the social security system" do not affect it ${ }^{27}$. Observed among other factors, education level has a positive impact on the habit of savings ${ }^{28}$. "Education and the free acquisition of information are important in paving the way for increased investment in stocks ${ }^{29}$. The head of the household is has the power for making life insurance purchasing decisions $\frac{30,31}{}$. There are a number of constraints, like distant geographic allocation, unfavorable and harsh rule, limited working time, procedural difficulties, degrading attitude of staff and complicated pattern of transaction ${ }^{32}$. In urban areas, household savings have a positive and significant impact with age, income, and size of land holdings ${ }^{\frac{33}{3}}$. This notion is not based on reality that poor cannot save $e^{32}$. Age is one of the determining factors that help in explaining the different saving patterns over time $\mathrm{e}^{34}$.

\section{Research Methodology}

This part of the study is aimed at devising a scheme of steps for analyzing the impact of general education level and the level of financial knowledge and information on financial inclusionin Pakistan. For achieving the objective of the study, the following step taken: In the first part of the interview schedule, questions were asked by interviewers, aimed at measuring the numeric financial literacy of the respondents and the questions were adopted from ${ }^{35}$. "The competent use of financial services requires additional knowledge, including awareness of consumer rights and understanding the functions of financial institutions." $\stackrel{3,36}{ }$. Keeping in view the findings of these researchers, questions, were asked about the working of financial institutions like banks, insurance companies and their services and products.

If a respondent was able to answer about, at least one of the functions of these institutions and at least one of their products and services, he was considered as having knowledge and information about financial institutions and services. Further, researchers have also identified demographic factors as significant determinants of the 
usage of financial services and products, therefore, in the second part of the questionnaire, contained closed ended questions, asked regarding the demographic profile of the interviewees. The respondents were considered as users of financial services if they have been or have ever used any of the financial services of banks and financial institutions like commercial banks and insurance companies. For analyzing the suitability of the interview schedule for collecting the required data, a pilot study was conducted. During the pilot study, 25 people were interviewed. The interview schedule was improved on the basis of the results of the pilot study by excluding some high level financial literacy as none of the respondents answered them correct. The improved interview schedule was sued for interviewing 150 (other than that the respondents interviewed in pilot study) respondents. The data were evaluated with the qualitative data analysis software NVIVO 10. As the dependent variable (the usage or nonusage of financial services), was a dichotomous variable, logistic and profit regression were used for evaluating the impact of independent variables on the dependent variables. In qualitative studies, ample size should be at last 31 interviews ${ }^{37}$.

\section{Results and Discussion}

The data gathered through conducting interviews has been analyzed with the help of NVIVO-10, software

Table 1.

\begin{tabular}{|c|c|cc|}
\hline S. No & Numeric literacy Question & & Answer \\
\hline 1. & $\begin{array}{c}\text { Suppose you had Rs. 100 in a saving account and the } \\
\text { interest rate was 2\% per year. After five years, how much } \\
\text { do you think you would have in the account if you left the } \\
\text { money to grow? }\end{array}$ & $\begin{array}{l}\text { A. } \\
\text { B. } \\
\text { C. }\end{array}$ & $\begin{array}{c}\text { More than Rs.102 } \\
\text { Exactly Rs.102 } \\
\text { Less than Rs.102 }\end{array}$ \\
\hline 2. & $\begin{array}{c}\text { Imagine that the interest rate on your saving account was } \\
1 \% \text { per year and inflation was 2\% per year, after one year, } \\
\text { how much would you be able to buy with the money in } \\
\text { this account? }\end{array}$ & $\begin{array}{l}\text { A. } \\
\text { B. }\end{array}$ & $\begin{array}{c}\text { More than today } \\
\text { Cxactly the same } \\
\text { Less than today }\end{array}$ \\
\hline 3. & $\begin{array}{c}\text { Please tell me whether this statement is true or false: } \\
\text { "Buying a single company's stock usually provides a safer } \\
\text { return than a stock mutual fund. }\end{array}$ & $\begin{array}{c}\text { True } \\
\text { False }\end{array}$ \\
\hline
\end{tabular}

Table 2. Numeric literacy and the usage of financial services

\begin{tabular}{|c|c|c|c|c|c|c|}
\hline \multirow{2}{*}{ Bank Account } & \multicolumn{2}{|c|}{ Interest Questions } & \multicolumn{2}{c|}{ Inflation Questions } & \multicolumn{2}{c|}{ Investment Questions } \\
\cline { 2 - 8 } & Incorrect & Correct & Incorrect & Correct & Incorrect & Correct \\
\hline No & 23 & 12 & 30 & 5 & 29 & 6 \\
\hline Yes & 60 & 55 & 85 & 30 & 70 & 45 \\
\hline \multicolumn{7}{|c|}{ Insurance Policy } \\
\hline No
\end{tabular}


Table 2 Continued

\begin{tabular}{|c|c|c|c|c|c|c|}
\hline \multicolumn{7}{|c|}{ Formal borrowing } \\
\hline No & 60 & 16 & 49 & 27 & 52 & 24 \\
\hline Yes & 55 & 19 & 66 & 8 & 63 & 11 \\
\hline
\end{tabular}

widely used for analysis of qualitative data. The following questions contained in Table 1 were aimed at measuring the numeric financial literacy of individuals. The results contained in Table 2 indicate that majority the of respondents gave an incorrect answer to the question posed for measuring numeric literacy but even then they had bank accounts or were using other financial services. Likewise respondents who answer correctly to financial literacy questions were not in use of financial services and products. On the basis of above results and discussion, it may be said that numeric financial literacy has an insignificant effect on the decision of the people regarding uses of financial services as indicated by the results, the $\mathrm{p}>.05$ as contained in the value of $B$ show mixed effect.

\section{The impact of Financial Knowledge and information on the Usage of Financial Services:}

The results, contained in Table 3, were obtained on the basis of questions:

- What do you know about the functions of a bank?

- What do you know about different types of bank accounts?

- Have you opened a bank account?

Table 3. Impact of financial knowledge on opening of bank accounts

\begin{tabular}{|c|c|c|c|c|}
\hline \multirow{2}{*}{ Bank Account } & \multicolumn{2}{|c|}{ Knowledge about of Banks } & \multicolumn{2}{|c|}{ Knowledge about Bank Accounts } \\
\hline & No & Yes & No & Yes \\
\hline No & 23 & 12 & 30 & 5 \\
\hline Yes & 2 & 113 & 2 & 113 \\
\hline \multicolumn{5}{|c|}{$\begin{array}{c}\text { Borrowing from } \\
\text { Banks }\end{array}$} \\
\hline No & 23 & 53 & 29 & 47 \\
\hline Yes & 2 & 72 & 3 & 71 \\
\hline \multicolumn{5}{|c|}{$\begin{array}{l}\text { Buying an Insurance } \\
\text { Policy }\end{array}$} \\
\hline No & 49 & 12 & 32 & 29 \\
\hline Yes & 3 & 86 & 1 & 88 \\
\hline
\end{tabular}


- Are you currently maintaining a bank account?

Table 3 shows that knowledge of about financial institutions and the services provided by them has certain impact on the usage of financial services and products by such institutions. Like as 87 and 83 respondents who had knowledge about banks and banks accounts had opened a bank accounts oppose toonly 02 people who either did not have knowledge about the working of financial institutions and types of banks account or they did not like to share their views, had opened banks accounts. There is a probability that someone else may have opened bank account for these individuals. The same is the case with other financial institutions and the services provided by them. The logistic regression results contained in that financial knowledge significantly affect financial inclusion as the $\mathrm{p}<.05$ and the $\mathrm{B}$ value is positive. The results are also supported by other researchers, understanding the consumer's insight and approach towards insurance and promoting an insurance culture is important inhelping the success of insurance services $\frac{16,38}{2}$. The Table 4 contains results about the level of trust of respondents in financial system and their decision of financial inclusion. According to the results, trust level has positive impact on financial inclusion. The logistic regression results contained in also confirms this as the $\mathrm{p}<0.05$ and $\beta$ is 0.941 .

Table 4. Trust and financial inclusion

\begin{tabular}{|c|c|c|c|c|c|}
\hline $\begin{array}{c}\text { Use of Financial } \\
\text { Services }\end{array}$ & $\begin{array}{c}\text { Having Trust } \\
\text { in Financial } \\
\text { institutions }\end{array}$ & $\begin{array}{c}\text { Not Having } \\
\text { Trust in } \\
\text { Financial } \\
\text { institutions }\end{array}$ & Urban & Rural & \\
\hline No Insurance & 50 & 18 & 13 & 22 & \\
\hline No Borrowing & 50 & 17 & 34 & 32 & \\
\hline No Bank Account & 22 & 13 & 20 & 41 & \\
\hline Insurance & 65 & 17 & 75 & 40 & \\
\hline Formal Borrowing & 65 & 18 & 45 & 29 & \\
\hline Bank Account & 89 & 26 & 75 & 14 & \\
\hline
\end{tabular}

Table 5. Educational level and the use of financial services

\begin{tabular}{|c|c|c|c|c|c|c|c|}
\hline Financial Services & Masters & Primary & Matric & Inter & Bachelor & M.Phil. & Middle \\
\hline No Bank Account & 08 & 4 & 4 & 5 & 6 & 3 & 5 \\
\hline No Borrowing from F.Is & 13 & 16 & 12 & 11 & 9 & 3 & 12 \\
\hline No Insurance policies & 10 & 16 & 9 & 7 & 9 & 6 & 4 \\
\hline Bank Account & 50 & 8 & 9 & 14 & 19 & 12 & 3 \\
\hline
\end{tabular}


Table 6. The impact of income level on financial inclusion

\begin{tabular}{|c|c|c|c|c|}
\hline Financial Services & $\mathbf{1 - 3 0 0 0 0}$ & $\mathbf{3 0 0 0 0 - 6 0 0 0 0}$ & $\mathbf{6 0 0 0 0 - 8 0 0 0 0}$ & $\mathbf{8 0 0 0 0}$ and above \\
\hline No Insurance & 23 & 11 & 14 & 22 \\
\hline No Borrowing & 19 & 22 & 5 & 7 \\
\hline No Bank Account & 27 & 18 & 26 & 13 \\
\hline Insurance & 3 & 18 & 17 & 17 \\
\hline Formal Borrowing & 5 & 23 & 26 & 53 \\
\hline Bank Account & 11 & 25 & 5 \\
\hline
\end{tabular}

Table 7. Impact of dependency ratio on the financial inclusion

\begin{tabular}{|c|c|c|c|c|c|c|c|c|c|c|}
\hline Financial Services & $\mathbf{0}$ & $\mathbf{1}$ & $\mathbf{2}$ & $\mathbf{3}$ & $\mathbf{4}$ & $\mathbf{5}$ & $\mathbf{6}$ & $\mathbf{7}$ & $\mathbf{8}$ & $\mathbf{1 0}$ and above \\
\hline No Insurance & 3 & 11 & 16 & 5 & 7 & 4 & 5 & 5 & 2 & 3 \\
\hline No Borrowing & 3 & 2 & 8 & 5 & 8 & 12 & 13 & 6 & 10 & 2 \\
\hline No Bank Account & 1 & 1 & 7 & 4 & 5 & 4 & 11 & 4 & 1 & 1 \\
\hline Insurance & 15 & 15 & 11 & 5 & 3 & 3 & 15 & 8 & 1 & 3 \\
\hline Formal Borrowing & 13 & 14 & 12 & 3 & 9 & 3 & 6 & 9 & 0 & 5 \\
\hline Bank Account & 25 & 16 & 12 & 13 & 12 & 11 & 9 & 5 & 6 & 6 \\
\hline
\end{tabular}

Table 8. Age and the use of financial services

\begin{tabular}{|c|c|c|c|}
\hline Use of Financial Services & Age $=\mathbf{1 8 - 4 0}$ & Age $=\mathbf{4 1 - 5 0}$ & Age $=\mathbf{5 0}$ and above \\
\hline No Insurance & 15 & 25 & 21 \\
\hline No Borrowing & 21 & 27 & 23 \\
\hline No Bank account & 23 & 25 & 20 \\
\hline Insurance & 23 & 46 & 16 \\
\hline Formal Borrowing \\
Bank account
\end{tabular}


Table 9. Logistic regression analysis

\begin{tabular}{|c|c|c|c|c|c|c|c|}
\hline Independent Variables & $\beta$ & S.E. & Wald & Df & Sig. & $\operatorname{Exp}(\beta)$ & P-Value \\
\hline \multicolumn{8}{|l|}{$\begin{array}{c}\text { Answer to questions } \\
\text { about: }\end{array}$} \\
\hline Interest & -0.293 & 0.562 & 0.272 & 1 & 0.602 & 0.746 & 0.64 \\
\hline Inflation & -0.847 & 1.142 & 0.55 & 1 & 0.458 & 0.429 & 0.51 \\
\hline Investment & 2.033 & 1.153 & 3.11 & 1 & 0.078 & 7.636 & 0.88 \\
\hline $\begin{array}{l}\text { Working of financial } \\
\text { institutions }\end{array}$ & 5.4210 & 1.0650 & 25.9140 & 1.0000 & 0.0000 & 226.0000 & 0.904 \\
\hline financial products & 5.6350 & 0.8420 & 44.7870 & 1.0000 & 0.0000 & 280.0000 & 0.9493 \\
\hline \multicolumn{8}{|c|}{ Education: } \\
\hline Primary & -2.93 & 1.441 & 4.133 & 1 & 0.042 & 0.053 & 0.095494 \\
\hline Middle & -0.856 & 0.495 & 2.989 & 1 & 0.084 & 0.425 & 0.458464 \\
\hline Matric & 0.082 & 0.238 & 0.12 & 1 & 0.729 & 1.086 & 0.683876 \\
\hline Intermediate & 0.836 & 0.303 & 7.594 & 1 & 0.006 & 2.307 & 0.821286 \\
\hline Bachelor & 0.127 & 0.107 & 1.397 & 1 & 0.237 & 1.135 & 0.693338 \\
\hline Master & 6.433 & 1869.162 & 0 & 1 & 0.997 & 621.982 & 0.999194 \\
\hline M.Phil & -2.777 & 1227.396 & 0 & 1 & 0.998 & 0.062 & 0.109928 \\
\hline Location: & 1.386 & 0.406 & 11.685 & 1 & 0.001 & 4 & 0.863 \\
\hline Age: & -.377 & .512 & .544 & 1 & .461 & .686 & 0.666667 \\
\hline Constant & 1.070 & .335 & 10.239 & 1 & .001 & 2.917 & 0.744617 \\
\hline
\end{tabular}

Trust is positively associated with participation in financial markets ${ }^{2,39}$. Results contained in Table 4 further and confirms that location has a significant impact on the usage of financial services and products as the results indi- cates that for urban areas the $\mathrm{p}<.05$ for and the $\mathrm{B}$ is 1.386 as whereas for rural areas the $p>0.05$ and the $B$ is 0.46 . Likewise the probability of usage of financial services for urban areas is $81 \%$ whereas for rural areas it is $61 \%$. It con- 
firms the findings of other researchers' like ${ }^{31}$. The Table 5 contains the results about the impact of general education on the use of financial services. The results indicate that level of education of individuals has a positive impact on financial inclusion as the $\mathrm{p}<0.05$ and $\beta=6.433$ shown by the results of logistic regression. Results contained in Table 6 indicate that financial inclusion increases with increasing level of income. The Table 7 shows that people, who have very low number of dependents, save or invest lesser amount when compared to those people who have average number of dependents. The reason may be that such people care less worried about their future expenditures. The Table 8 contains results about the impact of age on the use of savings and investment services. The results indicate that middle aged people ranging from 41-50 are the major participants in the financial markets. Financial capability is expected to increase with age ${ }^{40}$. However, the logistic regression results contained in Table 9 shows that age has no significant impact on the usage of financial services in Pakistan.

\section{Conclusion}

It can be safely concluded that the role of numeric financial literacy in determining the level of financial inclusion was very low. It means that mere awareness of the basis financial terms like inflation, interest and investment has very low impact on the decision about financial inclusion. On the other hand information and knowledge about financial institutions, their working and services provided by them have a greater impact on the usage of financial services. The other control variables showed mixed results. Whereas people residing in rural areas are discouraged to use financial services while people in urban areas more frequently use basic financial services.

\subsection{Limitations of the Study}

Owing to resource limitations, the study is limited only to a few selected cities of Pakistan. The sample of the study is comprised only of men; representation has not been given to women of Pakistan. The major reason for this limitation was that in rural areas, communicating with women by a stranger is not appreciated. In future, researchers may carry out studies, on the basis of large sample size, giving equitable representation to different segments of the society. Apart from including demographic factors like income, dependency ratio and gender, psychological factors like trust in financial institutions and religious orientation may be used as independent variables for studying financial market participation in the country.

\section{References}

1. Badarinza C, Campbell JY, Ramadorai T. International comparative household finance. Annual Review of Economics. 2016; 8(1):111-44. https://doi.org/10.1146/annurev-economics-080315-015425.

2. Guiso L, Sapienza P, Zingales L. Trusting the stock market. Journal of Finance. 2008; 63(6): 2557-600. https://doi. org/10.1111/j.1540-6261.2008.01408.x.

3. The impact of financial literacy on use of financial services in Russia. 2010. https://getd.libs.uga.edu/pdfs/kunovskaya_ irina_201005_phd.pdf.

4. Access to financial services and the financial inclusion agenda around the world: A cross-country analysis with a new data set. 2011. https://elibrary.worldbank.org/doi/ abs/10.1596/1813-9450-5537.

5. Migap JP, Okwanya I, Ojeka, G. Financial inclusion for inclusive growth: The Nigerian perspective. International Journal of Information Technology and Business Management. 2015; 37(1):1-8.

6. Huston SJ. Measuring financial literacy. Journal of Consumer Affairs. 2010; 44(2):296-316. https://doi.org/10.1111/ j.1745-6606.2010.01170.x.

7. Huston SJ. The concept and measurement of financial literacy: Preliminary results from a new survey on financial literacy assessment. Conference Presentation in Academy of Financial Services Annual Conference. 2009; 9:1-9.

8. Hastings JS, Madrian BC, Skimmyhorn WL. Financial literacy, financial education and economic outcomes. Annual Review of Economics. 2013; 5(1):347-73. PMid: 23991248 PMCid: PMC3753821. https://doi.org/10.1146/annureveconomics-082312-125807 .

9. Promoting Financial Inclusion and Literacy in Pakistan via G2P Payment Programs. 2012. http://www.microfinanceconnect.info/assets/articles/Promoting\%20Financial\%20 Inclusion \% 20and\%20Literacy\%20in \%20 Pakistan_ October\%202012_PMN.pdf. 
10. Wealth decumulation, portfolio composition and financial literacy among European elderly. 2014. https://econpapers. repec.org/paper/ccawpaper/375.htm.

11. Van Campenhout G. Revaluing the role of parents as financial socialization agents in youth financial literacy programs. Journal of Consumer Affairs. 2015; 49(1):186222. https://doi.org/10.1111/joca.12064.

12. Ellis $\mathrm{K}$, Lemma A. Investigating the impact of access to financial services on household investment. Overseas Development Institute; 2010. p. 1-75.

13. Collins JM, O'rourke CM. Financial education and counseling-Still holding promise. Journal of Consumer Affairs. 2010; 44(3):483-98. https://doi.org/10.1111/j.17456606.2010.01179.x.

14. Seth P. Financial literacy and investment decisions of retail investors in Delhi. International Journal of Science, Technology and Management. 2015; 4(1):1-10.

15. Murendo C, Mutsonziwa K. Financial literacy and savings decisions by adult financial consumers in Zimbabwe. International Journal of Consumer Studies. 2017; 41(1):95103. https://doi.org/10.1111/ijcs.12318.

16. Negi D, Singh P. Demographic analysis of factors influencing purchase of life insurance products in India. European Journal of Business and Management. 2012; 4(7):169-80.

17. Financial knowledge and best practice behavior. 2011. https://afcpe.org/assets/pdf/vol_22_issue_1_robb_woodyard.pdf.

18. Delafrooz N, Paim LH. Determinants of saving behavior and financial problem among employees in Malaysia. Australian Journal of Basic and Applied Sciences. 2011; 5(7):222-8.

19. Sevim N, Temizel F, Sayılır O. The effects of financial literacy on the borrowing behaviour of Turkish financial consumers. International Journal of Consumer Studies. 2012; 36(5):573-9. https://doi.org/10.1111/j.14706431.2012.01123.x.

20. A formal theory of knowledge and action. 1994. https:// www.sri.com/sites/default/files/uploads/publications/ pdf/632.pdf.

21. Zak PJ, Knack S. Trust and growth. The Economic Journal. 2001; 111(470):295-321. https://doi.org/10.1111/14680297.00609 .

22. Dearmon J, Grier K. Trust and development. Journal of Economic Behavior and Organization. 2009; 71(2):210-20. https://doi.org/10.1016/j.jebo.2009.02.011.

23. Chhaochharia V, Kumar A, Niessen-Ruenzi A. Local investors and corporate governance. Journal of Accounting and Economics. 2012; 54(1):42-67. https://doi.org/10.1016/j. jacceco.2012.03.002.
24. Zhan M, Grinstein-Weiss M. Educational status and savings performance in Individual Development Accounts. Journal of Policy Practice. 2007; 6(1):27-46. https://doi. org/10.1300/J508v06n01_03.

25. Analysis of the determinants of the demand for financial services in rural Morocco. 2011. https://www.oecd.org/ countries/morocco/49304830.pdf.

26. Campbell JY. Household finance. The Journal of Finance. 2006; 61(4):1553-604. https://doi.org/10.1111/j.15406261.2006.00883.x.

27. Beck T, Webb I. Economic, demographic and institutional determinants of life insurance consumption across countries. The World Bank Economic Review. 2003; 17(1):51-88. https://doi.org/10.1093/wber/lhg011.

28. Osondu CK, Obike KC, Ogbonna SI. Savings, income and investment patterns and its determinants among small holder arable crop farmers in Umuahia Capital Territory, Abia State Nigeria. European Journal of Business and Innovation Research. 2015; 3(1): $51-70$.

29. Haliassos M, Bertaut CC. Why do so few hold stocks? The Economic Journal;1995. p. 1110-29. https://doi. org/10.2307/2235407.

30. Annamalah S. Profiling and purchasing decision of life insurance policies among married couples in Malaysia. World Applied Sciences Journal. 2013; 23(3): 296-304.

31. Wright G, Muteesassira L. The relative risks to the savings of poor people. Small Enterprise Development. 2001; 12(3):33-45. https://doi.org/10.3362/0957-1329. 2001.031.

32. Karlan D, Ratan AL, Zinman J. Savings by and for the poor: A research review and agenda. Review of Income and Wealth. 2014; 60(1):36-78. PMid: 25792764 PMCid: PMC4358152. https://doi.org/10.1111/roiw.12101.

33. Rehman HU, Bashir F, Faridi MZ. Saving behavior among different income groups in Pakistan: A micro study. International Journal of Humanities and Social Science. 2011; 1(10):268-77.

34. Curtis CC, Lugauer S, Mark NC. Demographics and aggregate household saving in Japan, China and India. Journal of Macroeconomics. 2017; 51:175-91. https://doi. org/10.1016/j.jmacro.2017.01.002.

35. Lusardi A. Household saving behavior: The role of literacy, information and financial education programs. Policymaking Insights from Behavioral Economics; 2007. p. $109-49$.

36. Cole SA, Sampson TA, Zia BH. Financial literacy, financial decisions and the demand for financial services: Evidence from India and Indonesia. Cambridge, MA: 
Harvard Business School; 2009. p. 9-117. PMCid: PMC2653028.

37. Mason M. Sample size and saturation in $\mathrm{PhD}$ studies using qualitative interviews. Forum qualitative Sozialforschung/ Forum: Qualitative Social Research. 2010; 11(3): 1-10.

38. Graham JR, Harvey CR, Huang H. Investor competence, trading frequency and home bias. Management Science. 2009; 55(7):1094-106. https://doi.org/10.1287/ mnsc.1090.1009.
39. Van Nieuwerburgh S, Veldkamp L. Information immobility and the home bias puzzle. The Journal of Finance. 2009; 64(3):1187-215. https://doi.org/10.1111/j.15406261.2009.01462.x.

40. Xiao JJ, Chen C, Sun L. Age differences in consumer financial capability. International Journal of Consumer Studies. 2015; 39(4):387-95. https://doi.org/10.1111/ijcs. 12205. 